\title{
PENINGKATAN PENGETAHUN MASYARAKAT TERKAIT PENTINGNYA REKAM MEDIS BAGI PASIEN DI FASILITAS PELAYANAN KESEHATAN
}

\author{
Romaden Marbun'1), Rea Ariyanti'1), Vincensia Dea') \\ 1)Program Studi Sarjana Terapan Manajemen Informasi Kesehatan, STIKes Panti Waluya, Malang, \\ Jawa Timur, Indonesia \\ Corresponding author : Vincensia Dea \\ E-mail : vincensiadhea@yahoo.com
}

Diterima 01 Oktober 2021, Direvisi 14 Oktober 2021, Disetujui 14 Oktober 2021

\begin{abstract}
ABSTRAK
Rekam medis merupakan bagian dari arsip yang menggambarkan segala aktivitas sebuah fasilitas pelayanan kesehatan dalam kurun waktu tertentu. Rekam Medis ialah berkas yang berisikan catatan dan dokumen tentang identitas pasien, pemeriksaan, pengobatan, tindakan, dan pelayanan lain yang telah diberikan kepada pasien. Rekam medis ini memiliki fungsi penting bagi pasien dan juga dokter. Oleh karena itu pengisian rekam medis ini harus lengkap dan tidak boleh ditunda pengisiannya baik bagi pasien ataupun tenaga kesehatan. Namun, banyak masyarakat yang belum mengetahui fungsi penting dari melengkapi rekam medis dan keterbukaan informasi pribadinya yang harus diberikan kepada fasilitas pelayanan kesehatan bahkan tenaga kesehatan yang merawatnya dalam menunjang mutu informasi pada rekam medis tersebut. Tujuan kegiatan ini adalah meningkatkan pengetahuan masyarakat khususnya RT 09 Kelurahan Bandulan Kota Malang tentang pentingnya rekam medis bagi masyarakat yang berobat di fasilitas pelayanan kesehatan. Metode penyuluhan dilakukan secara tidak langsung atau dalam jaringan (daring) dengan berkoordinasi via online grup whatsapp selama 3 kali pertemuan serta dikirimkan materi presentasi serta video pembelajaran. Masyarakat yang terlibat sebanyak 34 orang. Tahap evaluasi dilakukan melalui google form. Hasil kegiatan diperoleh peningkatan pengetahuan masyarakat dari rata-rata 37,53 menjadi 79,06 dengan point maksimal 100 . Kegiatan berjalan dengan baik dan perlu adanya monitoring lebih lanjut.
\end{abstract}

Kata kunci: pengetahuan; masyarakat; rekam medis; fasilitas pelayanan kesehatan.

\begin{abstract}
The medical record is part of the archive that describes all the activities of a health care facility within a certain period of time. Medical Record is a file that contains records and documents about the patient's identity, examination, treatment, action, and other services that have been provided to the patient. This medical record has an important function for patients as well as doctors. Therefore, the filling of this medical record must be complete and the filling should not be delayed either for the patient or the health worker. However, many people do not know the important function of completing medical records and the disclosure of personal information that must be provided to health care facilities and even health workers who take care of them in supporting the quality of information in the medical record. The purpose of this activity is to increase public knowledge, especially RT 09 RW 05 Kelurahan Bandulan Malang City about the importance of medical records for people who seek treatment at health service facilities. The counseling method is carried out indirectly or online by coordinating via online WhatsApp groups for 3 meetings and sending presentation materials and learning videos. There were 34 people involved. The evaluation stage is carried out through a google form. The results of the activity obtained an increase in public knowledge from an average of 37.53 to 79.06 with a maximum point of 100 . The activity went well and needed further monitoring.
\end{abstract}

Keywords: knowledge; public; medical records; health service facilities.

\section{PENDAHULUAN}

Ketika wabah Covid mulai ditetapkan sebagai pandemik oleh WHO (World Health Organization) atau Badan Kesehatan Dunia, semua masyarakat merasa panik tidak terkecuali masyarakat Kota Malang. Terlebih semua media dan pemberitaan yang secara serentak dipenuhi oleh berita-berita mengerikan tentang virus corona ini. Dari mulai orang-orang yang terinfeksi virus dimana penjalarannya sangat cepat hingga bisa membuat penderita kehilangan nyawa dalam waktu yang sebentar, proses penyebaran virus yang sangat cepat dan melalui kontak langsung, dan pemberitaan mengerikan lainnya. Kehadiran wabah pandemi COVID-19 tentunya banyak memberikan 
dampak dan pengaruh yang tidak biasa pada kehidupan masyarakat. Terlebih dampak kesehatan pada diri sendiri (Setyaningrum \& Yanuarita, 2020). Kondisi masyarakat ketika wabah ini membuat mereka mengalami anxiety (kecemasan) apabila tertular dan memeriksakan diri ke fasilitas pelayanan kesehatan ketika kurang enak badan sedikit saja (Fitria, Neviyarni, Netrawati, \& Karneli, 2020).

Fasilitas Pelayanan Kesehatan merupakan suatu tempat yang digunakan untuk menyelenggarakan atau menyediakakan berbagai upaya pelayanan kesehatan, baik dari segi promotif (promosi), preventif (pencegahan), kuratif (pengobatan) maupun rehabilitatif yang dilakukan oleh masyarakat dan pemerintah daerah. Puskesmas merupakan sebuah fasilitas pelayanan kesehatan yang menyediakakan upaya kesehatan perseorangan dan upaya kesehatan masyarakat mulai dari fasilitas tingkat pertama yang mengutamakan upaya promotif (promosi), dan preventif (pencegahan) untuk mencapai derajat kesehatan masyarakat yang setinggitingginya di suatu wilayah kerjanya (UndangUndang RI, 2014). Menurut Depkes RI (2008) setiap dokter atau dokter gigi yang ingin menjalankan atau menyediakakan praktik kedokteran di suatu pelayan kesehatan baik di puskesmas maupun di rumah sakit diwajibkan untuk membuat rekam medis (Departemen Kesehatan Republik indonesia, 2008).

Rekam Medis (medical record) ialah berkas yang berisikan catatan dan dokumen tentang identitas pasien, pemeriksaan, pengobatan, tindakan, dan pelayanan lain yang telah diberikan kepada pasien menurut Peraturan Menteri Kesehatan (Menteri Kesehatan Republik Indonesia, 2008).Rekam medis merupakan bukti tertulis tentang proses pelayanan diberikan oleh dokter dan tenaga kesehatan lainnya kepada pasien. Rekam medis berisi tentang data sosial pasien, riwayat penyakit, pemeriksaan, diagnosis, pengobatan dan tindakan medik lainnya. Dari pernyataan di atas maka rekam medik sudah seharusnya memuat informasi yang cukup mengenai pasien, diagnosa, dan alasan penetapan diagnosa. Pasien adalah setiap orang dalam masyarakat yang melakukan konsultasi masalah kesehatannya untuk memperoleh pelayanan kesehatan yang diperlukan baik secara langsung maupun tidak langsung kepada dokter atau dokter (Undang-Undang RI, 2004).

$$
\text { Setiap orang yang melakukan }
$$

konsultasi kesehatan ataupun untuk melakukan pengobatan tidak selalu harus ke rumah sakit ataupun puskesmas, namun juga dapat melakukannya di klinik atau fasilitas kesehatan lainnya.

Pengisian rekam medis harus dilakukan secara lengkap dan langsung pada waktunya dan tidak ditunda-tunda karena mutu pelayanan yang diberikan dirumah sakit antara lain akan tercermin pada berkas rekam medisnya. Menurut Keputusan Menkes Kesehatan RI Nomor : 129/Menkes/SK/II/2008 Tentang Standar Pelayanan Minimal Rumah Sakit, untuk jenis pelayanan Rekam Medis dengan indikator kelengkapan pengisian rekam medik 2x24 jam setelah selesai pelayanan, nilai standar $100 \%$ (Menteri Kesehatan Republik Indonesia, 2008).

Rekam Medis sendiri memiliki nilai guna baik bagi fasilitas pelayanan kesehatan itu sendiri, tenaga kesehatan yang merawat pasien atau bahkan bagi pasien yang berobat di fasilitas pelayanan kesehatan. Kepentingan rekam medis dilihat dari pemanfaatannya yaitu untuk pemeliharaan kesehatan dan pengobatan pasien; alat bukti dalam proses penegakan hukum, disiplin kedokteran dan kedokteran gigi dan penegakan etika kedokteran dan etika kedokteran gigi; keperluan pendidikan dan penelitian; dasar pembayar biaya pelayanan kesehatan; dan data statistik kesehatan (Suraja, 2019).

Fasilitas Pelayanan Kesehatan menjamin perlindungan hukum bagi dokter tenaga kesehatan agar tidak menimbulkan kesalahan medik dalam menangani pasien, sekaligus pasien mendapatkan perlindungan dari suatu tanggungjawab rumah sakit dan dokter tenaga kesehatan (Tutik, 2010). Salah satu indikator untuk menilai mutu suatu pelayanan kesehatan adalah dengan tersedianya rekam medis yang lengkap dan akurat. Tanpa kelengkapan dan keakuratan rekam medis menimbulkan kesan bahwa pelayanan kesehatan tidak berlangsung semestinya dan sulit membayangkan fakta aktual yang terjadi ini di sebabkan rekam medis merupakan kumpulan segala kegiatan para pelaksana kesehatan yang ditulis dan digambarkan atas aktivitas mereka terhadap pasien (Indar, 2010).

Setiap orang berhak memperoleh informasi tentang data kesehatan dirinya termasuk tindakan dan pengobatan yang telah maupun yang akan diterimanya dari tenaga kesehatan dan dapat ditelusur melalui rekam medis. Oleh karena rekam medis harus lengkap dan akurat, pasien maupun tenaga kesehatan harus mengetahui hak dan kewajiban yang dilakukannya saat berobat ke fasilitas pelayanan kesehatan dan pasien juga harus bersikat terbuka terhadap informasi medis yang harus diberikan kepada tenaga kesehatan 
untuk menunjang pelayanan dan menunjang mutu informasi yang ada pada rekam medis (Undang-Undang RI, 2009). Tetapi, masih banyak pasien yang kurang kooperatif dalam memberikan informasi medis dan melengkapi data pribadi pada rekam medis untuk menunjang mutu rekam medis pada fasilitas pelayanan kesehatan sehingga mutu pelayanan kesehatan tersebut masih tergolong buruk. Guna menghindari hal tersebut, maka perlu adanya edukasi bukan hanya kepada tenaga kesehatan melainkan kepada masyarakat yang berobat ke fasilitas pelayanan kesehatan.

Berdasarkan latar belakang tersebut, maka tim pengabdi tertarik untuk melaksanakan kegiatan Program Kemitraan Masyarakat (PkM) dengan judul "Edukasi Kesehatan terkait Pentingnya Rekam Medis bagi Masyarakat yang berobat pada Fasilitas Pelayanan Kesehatan di era Pandemi Covid-19 RT 09 Kelurahan Bandulan Kota Malang". Program kemitraan ini bertujuan untuk meningkatkan pengetahuan dan pemahaman masyarakat terhadap rekam medis dalam menunjang mutu dan nilai guna rekam medis bagi masyarakat yang berobat di fasilitas pelayanan kesehatan.

\section{METODE}

Program Kemitraan kepada Masyarakat (PkM) ini dilakukan di RT 09 Kelurahan Bandulan, Kota Malang dilakukan dengan metode berupa penyuluhan kesehatan terkait pentingnya rekam medis dan keterbukaan informasi medis di fasilitas pelayanan kesehatan. Sasaran kegiatan ini adalah 34 orang masyarakat di RT 09 yaitu 29 masyarakat dan 4 orang adalah kader kesehatan. Pelaksanaan penyuluhan dilakukan sebanyak 3 kali pertemuan secara tidak langsung atau dalam jaringan (daring) dengan berkoordinasi via online grup whatsapp serta dikirimkan materi presentasi, bentuk langsung rekam medis serta video pembelajaran dan dilanjutkan dengan diskusi interaktif.

Tahapan persiapan dilakukan dengan pendekatan kepada para tokoh yang terlibat mulai dari mengurus birokrasi dan permohonan ijin kepada pihak terkait, pertemuan dengan tokoh masyarakat dan kader kesehatan, mengobservasi masalah kesehatan sesuai dengan topik yang diambil lalu merencanakan waktu kegiatan bersama. Dengan ditetapkan bentuk kegiatan secara daring mengingat himbauan pemerintah terkait Pemberlakukan Pembatasan Kegiatan Masyarakat (PPKM) Jawa-Bali di era pandemi covid-19 untuk meminimalkan kegiatan berkumpul. Kegiatan pertama ditentukan bersama para kader kesehatan dan warga pada tanggal 01 Agustus
2021 dengan topik materi pentingnya rekam medis di fasilitas pelayanan kesehatan dan selanjutnya dilaksanakan sebanyak 2 (dua) kali yaitu pada tanggal 08 Agustus 2021 dan 10 Agustus 2021 dengan topik materi pentingnya melengkapi informasi di rekam medis dan keterbukaan informasi medis serta pemberian contoh bentuk dan pengisian rekam medis . Kegiatan Penyuluhan disampaikan oleh 2 pemateri yaitu Dosen dari Program Studi D-IV Manajemen Informasi Kesehatan.

Tahapan Monitoring dan Evaluasi dilaksanakan menggunakan lembar kuisioner berupa pretest dan post-test melalui media google form. Evaluasi dilakukan terhadap reaksi para kader kesehatan dan warga baik melalui pertanyaan pretest dan post-test terkait pemahaman materi yang disampaikan melalui media pembelajaran yang disampaikan. Secara garis besar, pertanyaan yang dicantumkan pada pre-test dan post-test adalah pertanyaan seputar rekam medis di fasilitas pelayanan kesehatan dan hubungannya rekam medis dengan masyarakat yang berobat di fasilitas pelayanan kesehatan tersebut seperti definisi rekam medis, keterbukaan informasi medis, kepemilikan rekam medis, dan nilai guna rekam medis.

\section{HASIL DAN PEMBAHASAN}

Berdasarkan pengkajian awal yang dilakukan dengan perangkat desa dan kader di RT 09 , diketahui bahwa para masyarakat minim pengetahuan terkait apa saja yang ada di fasilitas kesehatan mulai dari sistem alur pelayanan kesehatan, syarat berobat, bagian yang terdapat di fasilitas pelayanan kesehatan dan serta prosedure apabila ada komplain atau pelayanan yang kurang dari fasilitas pelayanan kesehatan dan minim sekali pengetahun warga terkait berkas catatan medis pasien atau rekam medis. Ditambah dengan dampak dari pandemi yang dirasa oleh masyarakat pada fasilitas pelayanan kesehatan adalah kurangnya pelayanan dan informasi yang diberikan kepada masyarakat hingga penolakan. Berdasarkan hal tersebut, maka tim pengabdi bersama dengan tim pengelola membuat prioritas masalah dan menentukan pelaksanaan kegiatan yang diikuti oleh 29 masyarakat dan 4 kader kesehatan di RT 09.

Dari hasil pengkajian awal disepakati bahwa kegiatan dilaksanakan sebanyak 3 kali dengan topik Pentingnya Rekam Medis, Pentingnya Rekam Medis, Pentingnya melengkapi rekam medis dan keterbukaan informasi medis pada fasilitas pelayanan kesehatan dan contoh berkas dan pengisian rekam medis dan dilakukan secara daring mengingat adanya pembatasan kegiatan 
masyarakat untuk berkumpul karena pandemi covid-19. Dalam pengkajian awal tersebut juga dilakukan penyebaran kuisioner secara online kepada masyarakat untuk mengidentifikasi distribusi karakteristik masyarakat dan kader kesehatan di RT 09 Kelurahan Bandulan Kota Malang (Tabel 1).

Tabel 1. Distribusi Frekuensi peserta PKM

\section{KATEGORI FREK. PERSENTASE} JENIS KELAMIN

\begin{tabular}{|c|c|c|}
\hline \multicolumn{3}{|c|}{ JEINIS KE } \\
\hline LAKI-LAKI & 9 & $26,5 \%$ \\
\hline PEREMPUAN & 25 & $73,5 \%$ \\
\hline TOTAL & 34 & $100 \%$ \\
\hline \multicolumn{3}{|c|}{ PENDIDIKAN TERAKHIR } \\
\hline $\begin{array}{l}\text { TIDAK } \\
\text { BERSEKOLAH }\end{array}$ & 14 & $41,2 \%$ \\
\hline SD-SMA/SMK & 15 & $44,2 \%$ \\
\hline $\begin{array}{l}\text { PERGURUAN } \\
\text { TINGGI }\end{array}$ & 5 & $14,7 \%$ \\
\hline TOTAL & 34 & $100 \%$ \\
\hline \multicolumn{3}{|c|}{ STATUS PEKERJAAN } \\
\hline BEKERJA & 19 & $55,9 \%$ \\
\hline $\begin{array}{l}\text { TIDAK } \\
\text { BERKERJA }\end{array}$ & 15 & $44,1 \%$ \\
\hline TOTAL & 34 & $100 \%$ \\
\hline
\end{tabular}

Pelaksanaan kegiatan pertama dilaksanakan pada tanggal 01 Agustus 2021 secara daring melalui grup whatsapp. Sebelum melakukan kegiatan fasilitator memberikan pretest online dalam bentuk kuisioner pertanyaan melalui google form kepada masyarakat yang mengikuti kegiatan terkait topik materi yang diberikan. Selanjutnya fasilitator memberikan penyuluhan kepada masyarakat terkait Pentingnya Rekam Medis untuk pasien yang berobat di fasilitas pelayanan kesehatan dalam bentuk penyuluhan, kemudian dilanjutkan dengan memberikan kesempatan kepada masyarakat binaan dan kader kesehatan untuk melakukan diskusi dan tanya jawab (Gambar 1).

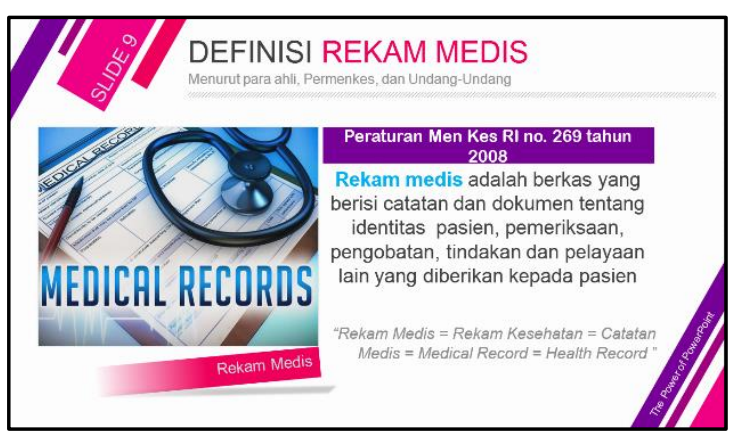

Gambar 1. Pemberian materi Hari ke-1

Pelaksanaan kegiatan kedua dilaksanakan pada tanggal 08 Agustus 2021 dan fasilitator memberikan penyuluhan dengan topik Pentingnya melengkapi rekam medis dan keterbukaan informasi medis pada fasilitas pelayanan kesehatan kepada masyarakat dan kader kesehatan. Pelaksanaan kegiatan ketiga pada tanggal 10 Agustus 2021 dengan materi penyuluhan yaitu memberikan contoh berkas rekam medis yang ada $d$ fasilitas pelayanan kesehatan dan contoh pengisian pada formulir rekam medis yang dikemas oleh fasilitator dalam bentuk video pembelajaran (Gambar 2), kemudian dilanjutkan dengan memberikan kesempatan kepada masyarakat binaan dan kader kesehatan untuk melakukan diskusi dan tanya jawab serta diakhiri dengan memberikan post-test online dalam bentuk kuisioner melalui google form.

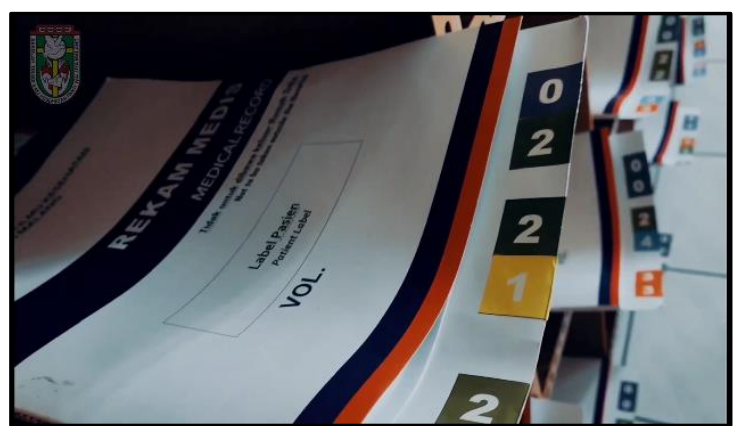

Gambar 2. Pemberian materi Hari ke-3

Dari hasil evaluasi didapatkan,
walaupun kegiatan dilakukan secara online/daring dengan metode penyuluhan dan diskusi interaktif melalui grup diskusi whatsapp serta pemberian video edukasi terkait materi yang diberikan, masyarakat dan warga memiliki antusiasme pada materi yang diberikan. Selain itu, evaluasi terkait pemahaman terhadap materi yang diberikan melalui kuisioner pertanyaan yang diberikan sebelum dan sesudah penyuluhan.

Dari Hasil analisa data yang dilakukan terhadap hasil pre-test dan post-test peserta, maka dapat diketahui bahwa telah terjadi peningkatan pemahaman terkait Edukasi Kesehatan terkait Pentingnya Rekam Medis bagi Pasien di Fasilitas Pelayanan Kesehatan. Peningkatan pemahaman ini dibuktikan dengan adanya peningkatan rata-rata point terhadap nilai pretest dan post test peserta yang dapat dilihat pada gambar 3 dan 4. Rata-rata point pre-test peserta sebelum diberikan penyuluhan adalah sebesar 37,53 dari point maksimal 100, sedangkan rata-rata point post-test peserta setelah diberikan penyuluhan adalah sebesar 79,06 dari point maksimal 100 . 


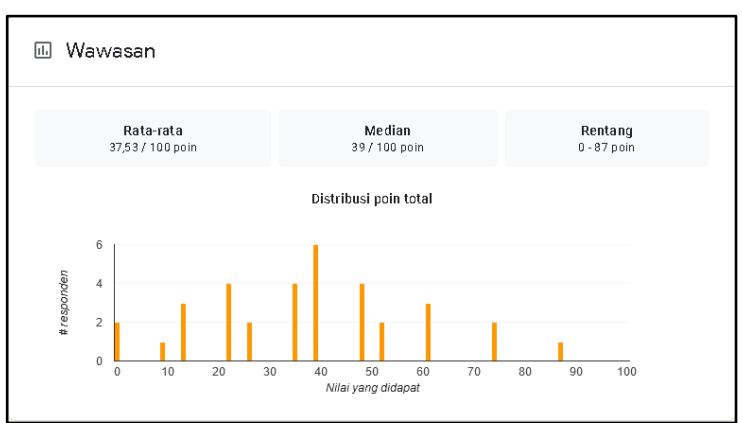

Gambar 3. Hasil Pre-Test wawasan peserta



Gambar 4. Hasil Post-Test wawasan peserta

Pelaksaan Program Kemitraan ini, tim pengabdi sempat mengalami beberapa kendala. Pada awalnya, Pelaksanaan PkM disepakati akan dilaksanakan daring via zoom agar dapat leluasa dalam penyampaian materi dan pemberian contoh secara nyata, akan tetapi karena keterbatasan kemampuan masyarakat dan keterbatasan jaringan telekomunikasi dan gawai maka diputuskan untuk melalui diskusi grup whatsapp dan pemberian link video dan materi penyuluhan.

Kelengkapan dokumen rekam medis merupakan hal yang sangat penting karena berpengaruh terhadap proses pelayanan yang dilakukan oleh petugas medis dan mempengaruhi kualitas dari pelayanan suatu rumah sakit (Sukma, 2008). Ketidaklengkapan pengisian rekam medis menggambarkan pelayanan kesehatan yang diberikan dan mutu pelayanan rekam medis. Dokumen rekam medis yang tidak lengkap akan menyebabkan petugas kesehatan kesulitan dalam mengenali riwayat penyakit pasien dan klaim kepada pihak asuransi.

Perlunya masyarakat mengetahui rekam medis dan perlunya keterbukaan informasi medis karena berkaitan dengan nilai guna rekam medis tersebut baik bagi pasien , tenaga kesehatan maupun fasilitas pelayanan kesehatan tersebut. Hal pertama yang harus dilakukan sebelum ada tindakan terhadap pasien pada fasilitas kesehatan sangat erat kaitannya dengan rekam medis, seperti melengkapi data pasien, keluhan pasien dan lain sebagainya. Namun, banyak diantara masyarakat kita tidak memahami hal tersebut maka perlunya edukasi terkait rekam medis pada masyarakat. Data rekam medis dan semua isi yang terdapat didalamnya merupakan data pribadi yang tidak boleh disebarluaskan kepada siapa saja. Di era BPJS saat ini, rekam medis menjadi sangat penting bagi fasilitas kesehatan, sehingga diperlukan juga pofesional rekam medis yang handal diposisi tersebut (Mardi \& Kamal, 2019).

Sebagian besar pengetahuan manusia diperoleh melalui mata dan telinga seperti poster, majalah, atau sumber informasi yang berbentuk tulisan dan informasi yang berbentuk suara seperti seminar, penyuluhan, atau pembicaraan dari orang lain melalui percakapan sehari-hari. Penyuluhan yang dilakukan dengan metode yang tepat dapat menarik perhatian serta mempermudah pemahaman terhadap penyuluhan yang diberikan. Dengan diberikannya penyuluhan, maka responden yang semula belum mengetahui menjadi mengetahui dan memahami, sehingga diharapkan dapat meningkatkan perilaku kesehatannya (Ariyanti, Sigit, \& Anisyah, 2021).

\section{SIMPULAN DAN SARAN}

Pengabdian kepada Masyarakat mengenai Pentingnya Rekam Medis bagi Pasien di Fasilitas Pelayanan Kesehatan ini telah terlaksana dengan baik secara daring dengan pemberian materi, diskusi dan tanya jawab interaktif, serta pemberian video edukasi. Hasil evaluasi kegiatan diketahui bahwa adanya peningkatan pengetahuan terhadap pemahaman masyarakat dan kader kesehatan di RT 09 Kelurahan Bandulan Kota Malang. Hal ini dapat dilihat dari hasil pretest dan post-test kegiatan Program Kemitraan Masyarakat (PkM). Rata-rata point pre-test peserta sebelum diberikan penyuluhan adalah sebesar 37,53 dari point maksimal 100 , sedangkan ratarata point post-test peserta setelah diberikan penyuluhan adalah sebesar 79,06 dari point maksimal 100. Diharapkan dengan adanya peningkatan pengetahuan ini, para masyarakat dan kader kesehatan lebih memahami tentang bagian-bagian yang ada di fasilitas pelayanan kesehatan khususnya Unit Rekam Medis guna mencapai mutu yang baik di fasilitas pelayanan kesehatan.

\section{UCAPAN TERIMAKASIH}

Pengabdi mengucapkan terima kasih kepada perangkat desa dan warga RT 09 Kelurahan Bandulan, Kecamatan Sukun, Kota Malang yang bersedia menjadi subjek binaan dalam pengabdian kepada masyarakat ini. Tidak lupa pula pengabdi mengucapkan terima kasih kepada STIKes Panti Waluya Malang 
yang membiayai kegiatan pengabdian kepada masyarakat ini.

\section{DAFTAR RUJUKAN}

Ariyanti, R., Sigit, N., \& Anisyah, L. (2021). Edukasi Kesehatan Terkait Upaya Swamedikasi Penyakit Osteoarthritis Pada Lansia. SELAPARANG Jurnal Pengabdian Masyarakat Berkemajuan, 4(3), 552. https://doi.org/10.31764/jpmb.v4i3.4779

Departemen Kesehatan Republik indonesia. (2008). Permenkes RI No 290/Menkes/Per/III/2008 Tentang Persetujuan Tindakan Kedokteran. Jakarta: Menteri Kesehatan RI.

Fitria, L., Neviyarni, Netrawati, \& Karneli, Y. (2020). Cognitive Behavior Therapy Counseling Untuk Mengatasi Anxiety Dalam Masa Pandemi Covid-19. AlIrsyad: Jurnal Pendidikan dan Konseling, 10(1), 23-29. Diambil dari http://jurnal.uinsu.ac.id/index.php/alirsyad/article/viewFile/7651/3538

Indar. (2010). Etika dan Hukum Kesehatan. Makassar: Lembaga Penerbitan Unhas.

Mardi, Y., \& Kamal, S. (2019). Meningkatkan Pemahaman Siswa Tentang Pentingnya Rekam Medis Pada Fasilitas Kesehatan. LOGISTA - Jurnal IImiah Pengabdian kepada Masyarakat, 3(2), 149. https://doi.org/10.25077/logista.3.2.149156.2019

Menteri Kesehatan Republik Indonesia. (2008). Keputusan Menteri Kesehatan RI No. 129/Menkes/SK/III/2008 tentang Standar Pelayanan Minimal Rumah Sakit. Jakarta: Departemen Kesehatan RI.

Menteri Kesehatan Republik Indonesia. (2008). Peraturan Menteri Kesehatan Republik Indonesia No. 269/Menkes/Per/III/2008 tentang Rekam Medis. Jakarta: Departemen Kesehatan RI.

Setyaningrum, W., \& Yanuarita, H. A. (2020). Pengaruh Covid-19 Terhadap Kesehatan Mental Masyarakat Di Kota Malang. JISIP (Jurnal IImu Sosial dan Pendidikan), 4(4). https://doi.org/10.36312/jisip.v4i4.1580

Sukma, I. (2008). Faktor Penyebab Ketidaklengkapan Dokumen Rekam Medis Pasien Rawat Inap Dalam Batas Waktu Pelengkapan di Rumah Sakit Umum Daerah Dr.Moewardi Surakarta. Izha Sukma Rahmadhani1, Sri Sugiarsi2, Antik Pujihastuti2, II(2), 82-89.

Suraja, Y. (2019). Pengelolaan Rekam Medis Pada Fasilitas Pelayanan Kesehatan. Jurnal Administrasi dan Kesehatan, 4(1), 62-71.
Tutik, T. T. (2010). Perlindungan Hukum bagi Pasien.

Undang-Undang RI. (2004). Undang-Undang Republik Indonesia No. 29 Tahun 2004 Tentang Praktik Kedokteran. Aturan praktik kedokteran. Jakarta.

Undang-Undang RI. (2009). Undang-Undang No 44 tahun 2009 tentang Rumah Sakit. Jakarta.

Undang-Undang RI. (2014). Undang-Undang No 36 Tahun 2014 tentang Tenaga Kesehatan. Jakarta. 